\title{
Experimental Teaching Method Research in "Career Management" from the Perspective of Applied Talent Cultivation in Universities
}

\author{
Yongfeng AN \\ Polytechnic College, Hebei University of Science and Technology, Shijiazhuang, Hebei, China
}

\begin{abstract}
Based on the applied talents training program, and combined with the practical application situation of experiential teaching mode in "career management" and the relevant courses in universities as well, this paper made a deep exploration and discussion in characteristics, methods and ideas of the experiential teaching method research, and measures and advice on proposed the platform building, faculty, curriculum modification and so on.
\end{abstract}

KEYWORD: applied talent cultivation; career management; experiential teaching method

With the development of education reform, "career management" has gradually got the attention from all walks of life. Applied talent cultivation mode has been the vital approach to talent cultivating in independent college. However, certain contradictions and problems are still existing in students' self-expectation and self-request, theorization and functionization of the course contents, and the "Injection type" teaching method in which the teacher were the main body and the experiential teaching method in which the students are the main body. Therefore, aiming at the professional ability training objectives, experiential teaching method is introduced. In teaching procedure, students' professional ability will be promoted gradually by the unconscious influence of the strategy of inspiration and interaction. In addition, Experiential teaching method being introduced in "career management" and relevant courses, experiencing teaching mode will be built on the basis of ability cultivation. Furthermore, multivariate cultivation mechanism of applied talents and corresponding teaching measures will be put forward as well. According to the literature research and the practical teaching experience, deep exploration and discussion of relevant contents will be made in this paper.

\section{CONCEPT IS PUT FORWARD}

Experiencing teaching method which is supported by the theory of "learning by doing" of Dewey, Experiential Learning Cycle of sociologist, Li Wen, and cognitive psychologist Piaget's theory of cognitive development, can be dated back to 1940s, In the teaching environment, students are the main body, they can experience and understand deeply the knowledge, the constitution mechanisms of substances, rules in occurrence and development of substances by sensing, constructing, and practicing the construction and the process of substances or the events, and then they can master multiple learning methods based on self-conscious and learning strategy.

Summarized from the existing research results at home and abroad, features of experiencing teaching method cover following aspects: first, it focuses on knowledge application, and aims to improve students' ability of solving practical problems via learned knowledge. Students' skills and knowledge can be improved from cognitive level, so it is practical; secondly, it focuses on self-experiencing and its core is individual experiencing and felling and reflection. It improves students' literacy from emotion and attitude level; thirdly, it focuses on situation creating, which is based on continuous and deep interaction between students and situation. It is situational from the perspective of conversion of the thoughts and roles; fourthly, students are the main body and teacher is just the guide in this teaching process. Students are the participants, experiencers, reflective thinkers. The teacher is the designer, organizer and counselor of teaching activities. Teaching procedure is the process of students' positive knowledge building by the teacher's guide, so it is subjective. 
2 APPLICATION OF EXPERIENCING TEACHING METHOD IN "CAREER MANAGEMENT"

As the central committee of the communist party of China about strengthening the deepening of the opinions of the college students' ideological and political education, a number of universities have set up career education courses. December, $28^{\text {th }}, 2007$, General office, the ministry of education promulgated Nem.7 file, College students' career development and employment guidance curriculum requirements in the requirement, it is emphasized that Career development and employment guidance course construction plays an important role in Colleges and universities personnel training and employment. It also requires to adopt career development education courses in university teaching plans, to strengthen teaching staff, to improve teaching contents and methods to guarantee the efficiency of career education courses.

\subsection{Basic approach}

Case Analysis Method. Case analysis Method in university career planning course means teacher offering relevant cases to students and asking questions about the cases, which can make students think, discuss and analyze in the given situation. By analyzing the familiar cases, teacher can tough students' emotions easier, can arouse students' consciousness of college students' career planning and the understandings of relevant knowledge, which help foster their analyzing ability by improving perceptual knowledge to rational knowledge.

Games. Students are asked to DIY or study autonomously in the class team and practical activity is the center of the team work. During the activity process, teacher can arouse students' learning interest, foster their team awareness and practical ability, improve their learning initiatives, then help them learn to think and analyze their values. Practical activities of class team can attract students, which can help them actively participate and experience in class activities and help to sublimate to generate ideas and emotions, then strengthen the teaching efficiency of career planning course.

Matches substituting classes. Under the management of the school career guidance center, various activities about career development will be organized. For example, arrange enterprise leaders to address on campus, or carry out some distinctive vocational guidance projects, such as individual coaching, simulation of interview, Professional diathesis developing activities, etc. matches can also be adopted, such as University students' career planning competition, College students' entrepreneurship and employment interview competition, etc. In the matches, students write career planning and venture plans, which can help them get familiar with their own professional plans and then begin to design entrepreneurship.

Scene simulation. Scene simulation is the base of experiencing teaching method. Students can immerse themselves in the situation quickly and perfect interaction effect will be obtained. In this part, the establishing of the situation need students' life experience, and combine their direct experience from life and indirect experience form class. When setting up situations, teacher insists on students' life reality, construct life classroom, and guide them observe life themselves, experience life with their own feelings, and study life with their own thoughts. Consequently, teacher has to set up precise situation, combine emotional reflection with own experience. Intellectual characteristic and enjoyment are both needed to attract students to guide students into specific situation and understand teaching contents. all of these help students think and improve their cognitive level the correctness of activity selecting. This teaching method is in favor of improving students' image thinking ability, letting students experiencing roles' level and function in life, then their analyzing and processing actual problem ability can be improved.

Lectures and report. This teaching method mainly embodied in two aspects: firstly, some universities have not form systematic career planning courses, or limited teaching staff force them to adopt this method; secondly, some universities invite enterprise leaders, alumnus, Specialists in Human Resources, etc, to participate in the course and carry out the thematic lectures. By this, students can more easily and more intuitively to obtain knowledge, students' interest and expanding thinking are aroused, making the students produce emotional resonance, and deepening the impression.

\subsection{The significance and application value}

\subsubsection{Create the workplace situation, guide experience and exploration}

Once career guidance curriculum break away from professional background, it will fall into the mire of the pure theoretical teaching. In teaching process, on the basis of teaching objectives and contents, the teacher choose fresh working materials, establish colorful situations and guide students to experience and feel, then stir up students' emotional experience. Students can feel and experience via making "truth" by "emotion" come into the hearts of students.

\subsubsection{Activity as the carrier in the experience internalization}

Vocational guidance courses is responsible for cultivating the students' occupational consciousness, 
innovative consciousness and ability to adapt to occupational changes, helping them to set up the correct professional ideal, the forming a good habit of ethical behavior. In teaching process, force only in rich and colorful activities can the external driving force is implemented and then can teaching objectives be carried out. Students' internal emotional experience will be aroused effectively, which can make them fell, experience and reflect autonomously. Consciously internalization offers opportunities to students to observe, to think, to participate and to operate. Attracting students to participate in the activities can guide students to internalize consciously on their own experience.

\subsubsection{Deepen and apply the experience to practice}

In the open society, career guidance course should also have open field of vision teachers should try hard to extend class to society, to encourage students learn out of class. Students are encouraged to immerse themselves in the society to experience by carrying out entrepreneurial practice, surveying, visiting and joining in community service, etc, which can help students master knowledge, internalized emotion and guide actions, and thus students can become subject of learning. Practical activities can improve students' experience professional ability and fulfill the specific requirements of the professional ethics. Students' professional moral emotion will be stirred unconsciously and the professional consciousness will be strengthened as well. Experiencing teaching method in career guidance course pours energy and vitality into course. As a kind of teaching idea, the practice of experiential teaching and improvement also need the operator deepen the research on the law of education teaching and the students' actual learning level.

\section{EXISTING PROBLEMS}

\subsection{Top-level design}

\subsubsection{Professional faculty construction}

Operators of university career guidance course are usually served by the teachers from Student Affairs Office or full-time tutors. These teachers have distinctive academic backgrounds, and most of them have to do administrative affairs, so they are lack of scientific training on career guidance course and theoretical research. Teachers have different teaching levels and do not have a full understanding of the true meaning of experiencing activities, therefore, in order to mobilize the classroom atmosphere experiencing activities appear, which makes the experiencing teaching method formalized.

\subsubsection{Lack of personalization}

Experiencing teaching method requires teachers to implement teaching process on the basis of students' various interest, characteristics and different cognitive levels. However, in university career guidance course, the testing instruments, cases and simulation activities are all lack of personalization, most of those are brought in from foreign countries or learned by teachers themselves. Most teachers do not do some in-depth study of the applicability of these activities, which made certain deviation of the activities of the effect and the evaluation results appear.

\subsection{Students' differences influence the teaching effect}

\subsubsection{Students lack of deep understanding of experiencing}

Students' awareness of career planning is weak, and they have little willingness to take the initiative to practice or explore in class. They do not have a correct attitude toward testing or activities, lack of deep thinking and reflection, which generate many problems, for examples, students do not have a full understanding of experiencing, teachers lack of pertinence when designing experiential teaching process, and lack of review and summarization of the experience of students, then weakened the degree of individual student's understanding of experience.

\subsubsection{Subject lack of practicality}

University career planning course is mainly presented by lectures or classroom teaching. Teachers ask students to experience by playing games, professional values auction, role playing or psychological tests, etc. However, the conclusions drawn from these activities are lack of testing. Universities are in short supply of corresponding experiencing platform, causing students lack of learning effect.

\subsection{Test way is difficult to divide the students grades}

In order to have a deep understand and develop experiencing teaching method, the writer conducted multi-dimensional simulation and practice during the teaching process, and in final exam, multi-angle test method was adopted to explore the effect of experiential teaching method. Summaries are the followings: firstly, case debate. In this part, students' ability of mastering and applying knowledge, in addition, the students' ability of thinking activity and expression, and other comprehensive qualities are tested. Secondly, have the basic theoretical test. 
With the method of comparative open questions in book-closed exam emphasize on the application of basic theoretical knowledge and expanding, involving scenario simulation, self-image, development thinking. Thirdly, write papers. Students are asked to writes related paper on the basis of practice and research and data analysis.

After examing the testing results, the writer believes that students have different attitudes to different testing ways. So in the future work, further exploration is needed, in order to fit into the contemporary college students' study and life, develop and promote experiential teaching method.

\section{STRATEGY FOR EXPERIMENTAL TEACHING METHOD}

\subsection{Create new experience platform}

Learning career planning should not only from the classroom to obtain knowledge and ability but also learn to integrate theory with practice, we need to know of the other as much as the other knows of us. Here "knowing ourselves" means knowing our character, interest and skills; "knowing others" means knowing the society. College students are in the exploration stage of career planning. Limited by campus environment and courses, college students have little chance to contact professional environment, so they have problems in applying what they have learned in class to practice. Universities, society and families ought to take active part in it, offering more experiencing platform. Students can contact with society as soon as possible, experiencing employment life, enhancing applying ability, then they can make a better choice. On the other hand, teacher should strengthen to guide students to actively look for experience opportunities, letting the students learn to choose an off-campus practice based on their own situation.

\subsection{Train professional teachers}

Teachers play a leading role in experiential teaching method, and their teaching level influence teaching effects. Therefore, teachers ought to be trained with theoretical knowledge and how to conduct activities to strengthen teachers' understanding and using of experiential activities, such as case teaching, experiential activities, behavior training, role exchanging, situation simulating, etc, the actionoriented teaching method taking the place of the traditional single teaching method means higher requirements on teachers. On one hand, teachers should know well about curriculum theoretical knowledge and skills to be a qualified "introducer", on the other hand, teachers should have the consciousness of professional ability training to explore various teaching methods.

\subsection{Write and adapt teaching materials}

Nowadays, teaching materials used in domestic career management and employment guidance courses pay attention to the theoretical knowledge or deduction and derivation of the model. But in reality, experiential teaching method help students understand and remember, students learned well. With growing cognitive levels, we should write and adapt teaching materials based on culture and thought progress. Combined contemporary teaching ideas with discipline construction, experiential teaching method can fulfill social needs.

\subsection{Carry out the school and practice base}

Strengthening intercollegiate, social interaction, paying attention to the cooperation between colleges and practice base of professional resources development at the same time is the strong pillar of the experiential teaching, is also an effective pattern to promote university students' professional ability. In "practical experience perception" phase, we focuses on students' professional ability and general ability of comprehensive training, and the ultimate goal is to have excellent performance in the work practice. So teachers and specialized departments should take active part in exploring Universityenterprise cooperation, practice bases and other professional resources to help students with "feedback of external application".

\section{REFERENCES}

[1] Dave Ellis.(1993)Career Planning. USA: Houghton Company

[2] David Kolb.(2006) learning styles model and experiential learning theory.

[3] James J. Kirk, Lynne D. Kirk.(1995) Training games for career development. USA: McGraw-Hill Inc.

[4] John Rod well. (1994) Partipative Training skills. Great Britain: Book craft (Bath) Ltd.

[5] Phillip S. Jarvis. (2006) Educators use career "Games", to Teach Lifelong Career Management Skills

[6] Louise welsh schrank. (1981) Life plan a practical guide to successful career planning. USA: National Textbook Company.

[7] Steven E. Books J.E. Althof, (1979), New Directions For Experiential Learning: Enriching the Liberal Arts Through Experiential Learning, San Francisco, Jossey-Bass Inc. Publishers, ppl53

[8] Burnard, P (1988) Experiential learning: Some theoretical Considerations, Journal of Lifelong Education, vol. 7, No. 20, pp 127-133.

[9] Jarvis, P(1995) Adult and Continuing Education: Theory and practice, London: Routedge, pp2.18. 